\title{
Factors Associated with Physical Spousal Abuse of Women During Pregnancy in Bangladesh
}

\begin{abstract}
CONTEXT: Violence toward pregnant women is a gross violation of human rights with adverse health consequences for the woman and potentially for her fetus; however, few studies have examined factors associated with such abuse in developing countries or with population-based data.
\end{abstract}

METHODS: A sample of 2,553 ever-pregnant women aged 15-49 from one urban and one rural site in Bangladesh were surveyed in 2001 as part of a World Health Organization multicountry study. Multilevel logistic regression analysis was used to examine factors associated with physical spousal abuse of women during pregnancy.

RESULTS: Urban and rural women whose mother or mother-in-law had experienced physical spousal abuse had increased odds of experiencing abuse during pregnancy (odds ratios, 2.1-3.4); increased spousal communication was negatively associated with the outcome in both settings (0.6 and 0.7). Among urban women, being older than 19, having a husband with more than 10 years of education and being from certain higher income quartiles were negatively associated with abuse (0.2-0.5); living in a community highly concerned about crime was positively associated with abuse (1.1). Among rural women, being able to depend on natal family support in a crisis was negatively associated with abuse (0.5); being in a marriage that involved dowry demands and being Muslim were positively associated with abuse (1.8 and 3.6, respectively).

CONCLUSIONS: The message that a family history of spousal violence increases a daughter's risk of such abuse should be widely communicated. Further research is needed to determine whether increased couple communication reduces the likelihood of violence or whether absence of violence leads to increased couple communication.

International Family Planning Perspectives, 2008, 34(2):71-78
By Ruchira Tabassum Naved and Lars Åke Persson

Ruchira Tabassum Naved is a scientist, Social and Behavioural Sciences Unit, International Centre for Diarrhoeal Disease Research, Bangladesh, Dhaka, Bangladesh; and Lars Åke Persson is head of international maternal and child health, Department of Women's and Children's Health, Uppsala University, Uppsala, Sweden.
Violence toward women during pregnancy has many farreaching consequences for a woman and her fetus, including serious social and health problems. ${ }^{1-4}$ Although the literature on this issue has grown in recent years, studies in developing countries and those using population-based data are scarce. In addition, previous studies vary greatly with respect to the definition of violence against women, sample size and composition, and reference periods. ${ }^{2,5}$

It is clear from the research that violence toward women during pregnancy is an issue that cuts across countries; however, prevalence varies from country to country, and even within countries. According to the majority of clinicbased studies in North America, the prevalence of violence during pregnancy ranges from $4 \%$ to $8 \% .^{2,5-7}$ An analysis of 1996-1998 Pregnancy Risk Assessment Monitoring System (PRAMS) data from 16 U.S. states estimated that the overall prevalence of physical violence during pregnancy was $5 \% ;^{8}$ the highest prevalence was in Oklahoma (7\%) and the lowest in Maine (4\%). Separate studies in North and South Carolina found the prevalence in those states to be $6 \%$ and $11 \%$, respectively. 9,10

According to a review of six studies from India, China, Pakistan and Ethiopia, the prevalence of physical violence during pregnancy ranged from $4 \%$ to $28 \% .{ }^{11}$ Four of these studies were hospital-based and found prevalence of
4-22\%; ${ }^{12-15}$ the other two were population-based, covering both urban and rural areas, and reported prevalence of 10-28\%. ${ }^{11,16,17}$ A multicountry, population-based study conducted by the World Health Organization (WHO), from which the data for the current study are drawn, shows that the rate of physical violence during pregnancy in 10 developing countries ranged from $3 \%$ to $28 \% .{ }^{18}$ This study addressed the problems of comparability by implementing standard methodology across the countries included in the study.

Eighteen percent of economically disadvantaged, currently married women living with their husbands in six villages in Bangladesh experienced physical violence during at least one pregnancy; for 3\%, the violence got worse during pregnancy. ${ }^{19}$ Using data from a population-based survey, the study detailed in this article explores the prevalence and characteristics of physical spousal abuse during pregnancy in rural and urban Bangladesh, and the factors associated with such violence.

\section{Who Are the Perpetrators?}

Most of the research on violence during pregnancy focuses on abuse by past or current intimate partners. Some researchers have included any experience of violence, regardless of the identity of the offender.9,20,21 According to 
a study of PRAMS data, $67 \%$ of perpetrators were husbands or partners; ${ }^{9}$ a more recent clinic-based study in the United States reported similar results. ${ }^{21}$ And in all countries in the WHO study, the partner with whom the woman became pregnant was the perpetrator in $89 \%$ of cases of violence during pregnancy. ${ }^{18}$

\section{Are Pregnant Women at Greater Risk?}

Although some abused women first experience violence during pregnancy, most do not. A Brisbane study of antenatal patients found that $18 \%$ of ever-abused women were first abused during a pregnancy. ${ }^{22}$ According to studies in Turkey $^{23}$ and Canada, ${ }^{7}$ however, about $86 \%$ of everabused women were abused for the first time when they were not pregnant. In addition, an analysis of nationally representative longitudinal U.S. data suggests that pregnant women are not at greater risk of victimization than nonpregnant women. ${ }^{24}$ Furthermore, the WHO multicountry study found that in most of the developing countries studied, the onset of physical violence did not overlap with pregnancy. ${ }^{18}$

The research results vary on whether violence toward women increases, decreases or remains the same during pregnancy. There is evidence that pregnancy can be a time of respite for some previously abused women, ${ }^{24-30}$ perhaps because of stigma associated with physically injuring a pregnant woman. ${ }^{23,26}$ If this is the case, partners might reduce the level of physical and sexual violence, only to replace it with emotional abuse, such as insults, threats and humiliation. ${ }^{23,31}$ The WHO multicountry study reports that the majority of women who suffered from violence before and during pregnancy in all sites reported that during the last pregnancy in which they were abused, the violence was the same or somewhat less severe or frequent than before the pregnancy. ${ }^{18}$ In contrast, other studies have found an escalation of violence during pregnancy. $7,25,32,33$ For example, $64 \%$ of Canadian women who were abused during pregnancy reported that their abuse increased during pregnancy. ${ }^{7}$

\section{Determinants of Violence Against Women During Pregnancy}

In most research, women who were abused during pregnancy had a history of abuse. ${ }^{34-36}$ Five studies found that a past history of abuse (i.e., abuse before pregnancy) is one of the strongest predictors of abuse during pregnancy. $7,28,31,37,38$ In addition, multiple social, economic, cultural, biological and environmental factors contribute to violence toward women during pregnancy.

- Social and demographic. Low socioeconomic status has consistently been identified as a risk factor for violence during pregnancy. $5,13,23,38,39$ Economically disadvantaged women, both in the United States and in developing countries, have the highest rates of reported abuse during pregnancy; ${ }^{40}$ although women from higher income groups experience violence, they may be less likely than others to disclose their abuse. ${ }^{17}$ Urban residence is a predictor of violence during pregnancy. ${ }^{23,38}$ In both developing and de- veloped countries, women's low level of education is associated with physical abuse during pregnancy; $6,13,15,23,41$ male partners' low level of education is also a contributing factor. ${ }^{12,15,17}$ Finally, young pregnant women are more likely than those who are older to be abused. $6,7,42,43$

- Relationship. Poor spousal communication is one of the factors associated with marital violence. ${ }^{44,45}$ Studies exploring the relationship between couple communication or interaction and physical violence during pregnancy are not numerous; however, according to at least two studies, poor couple communication is related to violence during pregnancy in India and China. ${ }^{13,38}$

- Community. According to the ecological framework and the existing literature, ${ }^{46,47}$ community-level factors influence violence against women: For example, neighborhood cohesion and informal social control capacity are negatively associated with both intimate homicide rates and nonlethal partner violence in the United States. ${ }^{48}$ In India, rates of violent crime were positively associated with domestic violence against women. ${ }^{49}$

\section{METHODS}

\section{Design and Procedures}

The data used in this article come from a cross-sectional, population-based survey of Bangladeshi women aged 15-49 conducted from June 25 to November 25, 2001. The survey was part of the WHO Multi-Country Study on Women's Health and Domestic Violence Against Women, which explored violence against reproductive-age women with a special focus on spousal violence. Our study was approved by the ethical review committee of the research institution in Dhaka, Bangladesh.

The data were collected from one urban area and one rural area in eastern Bangladesh. The urban area is a large city that has an extremely dense population and high inmigration rates. The rural site is regularly flooded and is dominated by subsistence agriculture; however, about $56 \%$ of its households are functionally landless (i.e., own less than 50 decimals of cultivable land). More than 95\% of the population in each is Muslim. ${ }^{50}$ The level of education is low, with two out of five adults having no schooling. Most families are poor, although contrasts in socioeconomic status are much greater in the urban area.

These locations were chosen because they are areas where support services for abused women are currently available or could be established, the populations are broadly representative of socioeconomic strata and religions found within the country and the populations are not already marginalized and not perceived as having high levels of domestic violence. The first criterion was supposed to ensure service to the surveyed women as part of the ethical obligation of the research; its inclusion made site selection purposive. The other criteria were added to minimize bias in site selection.

A multistage sampling strategy was used. In the urban site, the primary sampling units were mohollas (i.e., the smallest administrative units); in the rural site, the prima- 
ry sampling units were villages. Within the two sites, primary sampling units were selected randomly. Forty-two rural clusters and 39 urban clusters were selected for the survey. Sample households were randomly selected from each primary sampling unit, with probability of selection proportionate to size. In the rural area, the household list was obtained from the International Centre for Diarrhoeal Disease Research, Bangladesh's health and demographic surveillance system, which is updated monthly. In the urban area, the number of households in each cluster was obtained from the 1991 population census. Every sixth household in a cluster starting from the northeast was included in the sample. The first household in the cluster was selected randomly from the first six households on the right-hand side. A household was defined as a unit consisting of people sharing the same stove.

The surveys were conducted by interviewers trained in gender issues, handling sensitive issues and managing difficult situations arising out of discussion of these issues, confidentiality, and safety and protection of the women participating in the study. The age and initials of all females in a selected household were recorded on a household form from which women eligible for interviewing (i.e., those aged 15-49) were identified. For confidentiality and safety, only one woman in each household was interviewed; one woman was randomly selected from households with two or more eligible women. If the woman selected was not available to be surveyed, the interviewer made an appointment to return. Two additional visits were made before the woman was considered lost to follow-up. Overall, our survey sample consisted of 3,130 reproductive-aged women.

\section{Measurements}

- Dependent variable. Experience of physical assault perpetrated by one's partner during any pregnancy was the dependent variable in the analyses. To assess this variable, the survey questionnaire included the introductory statement and the question "You said that you have been pregnant _ times. Was there ever a time when you were beaten or physically assaulted by (any of) your partner(s) whilst you were pregnant?" Women who answered yes were asked the number of pregnancies in which this occurred and if they had ever been punched or kicked in the abdomen while pregnant. In addition, abused women were asked the following questions about the last pregnancy during which they were abused: whether the perpetrator was the partner with whom they became pregnant, whether they were living with that partner at the time, whether they had been beaten by that partner before becoming pregnant and if so, whether the mistreatment increased, decreased or remained about the same during the pregnancy.

The questions on violence during pregnancy were modified versions of questions used by Campbell ${ }^{27}$ and those developed by the Centers for Disease Control and Prevention (CDC) for the PRAMS model in the United States. ${ }^{51}$ Psychometric analysis was performed on the violence questions to ascertain the appropriateness of the behavioral items included. ${ }^{18}$ The items had good internal consistency, indicating that the instrument provided a reliable and valid measure of violence during pregnancy.

- Independent variables. Women answered questions about their age, their husband's level of education, whether they earned income, whether they participated in a savings or credit group, whether their mother had been physically abused by her husband, whether their motherin-law had been physically abused by her husband, whether their marriage had involved dowry demands and whether they lived with their in-laws. Religion was treated as an independent variable for rural women, but not for urban women, because there were not enough non-Muslims (Hindus in this context).

In addition, an index representing the extent of spousal communication was constructed from women's answers to four items assessing whether a couple talked about what happened to each partner during the day and each partner's worries (yes $=1 ;$ no $=0$ ). The index ranged from 0 to 4 , with 4 indicating the highest level of communication.

Furthermore, interviewers collected information on household socioeconomic status and concerns regarding crime level in the neighborhood from an adult household member prior to selecting a female from the household to be interviewed. A single question on the total annual household income was used to construct income quartiles. Income quartiles were calculated separately for urban and rural areas, as the income levels in these settings differed sharply, with much lower income levels in the rural area. Concern regarding crime was assessed by asking women, "Are you concerned about the levels of crime in your neighborhood (like robberies or assaults)? Would you say that you are not at all concerned, a little concerned, or very concerned?" Those who answered "very concerned" were coded as 1 , and others were coded as 0 . Individual responses were aggregated within each village or moholla.

In conducting this study, we paid particular attention to ethical and safety considerations. For the sake of confidentiality, the survey was introduced at the local and household level as a survey of women's health and life experiences. The interviews were conducted in private and in a nonjudgmental manner. Counseling services were offered to women reporting ever experiencing physical or sexual violence by their husband and to those reporting a high distress level. Distress level was measured by the 20-item Self-Reporting Questionnaire developed by WHO and validated and used in many countries, including India. ${ }^{52}$

\section{Analysis}

For our analysis, we selected the 2,553 ever-pregnant women (1,273 urban and 1,280 rural) from the survey sample. We calculated the number and proportion of women who experienced spousal physical violence during any pregnancy, women's number of pregnancies in which they were abused, the proportion of women whose 


\begin{tabular}{|c|c|c|}
\hline Characteristic & $\begin{array}{l}\text { Urban } \\
(\mathrm{N}=1,280)\end{array}$ & $\begin{array}{l}\text { Rural } \\
(\mathrm{N}=1,273)\end{array}$ \\
\hline \multicolumn{3}{|l|}{ Age-group** } \\
\hline $15-19$ & 6.7 & 6.2 \\
\hline $20-24$ & 18.5 & 15.6 \\
\hline $25-29$ & 24.6 & 21.3 \\
\hline$\geq 30$ & 50.1 & 57.0 \\
\hline \multicolumn{3}{|l|}{ Husband's education (yrs.)*** } \\
\hline None & 13.3 & 38.4 \\
\hline $1-5$ & 6.0 & 11.5 \\
\hline $6-10$ & 24.7 & 31.8 \\
\hline$\geq 11$ & 56.1 & 18.3 \\
\hline Earns income ${ }^{* * *}$ & 15.2 & 21.1 \\
\hline Member of savings/credit group*** & 13.0 & 31.3 \\
\hline Marriage involved dowry demands*** & 14.1 & 53.0 \\
\hline In-laws live in household $* * *$ & 23.1 & 36.4 \\
\hline May depend on natal family support in crisis & 86.2 & 85.6 \\
\hline Mean level of spousal communication (range, $0-4$ ) & 3.1 & 3.1 \\
\hline Mother was abused by her husband $d^{* * *}$ & 15.2 & 9.6 \\
\hline Mother-in-law was abused by her husband ${ }^{* *}$ & 13.4 & 17.1 \\
\hline Muslim*** & 94.9 & 83.4 \\
\hline High concern about level of crime in community**,+ & 14.7 & 8.4 \\
\hline
\end{tabular}

first experience of violence occurred during pregnancy and the proportion of women who reported any change or no change in the level of violence from the prepregnancy period to the period during which they were pregnant. Chi-square and t-tests were used to examine differences between urban and rural settings.

We conducted multilevel logistic regression to analyze the determinants of spousal violence during pregnancy. According to the literature, neighborhood-level variables are related to intimate partner violence against women and the presence of such variables modifies the relationship between the individual-level variables and violence. ${ }^{47}$ Use of multilevel models helped to account for the possibility of similarities among women living in the same community and to assess the effect of a community-level factor (i.e., concern regarding the level of crime in the community). Separate analyses for urban and rural areas were

\begin{tabular}{|c|c|c|}
\hline Characteristics & Urban & Rural \\
\hline All women & $(\mathrm{N}=1,280)$ & $(\mathrm{N}=1,273)$ \\
\hline Ever physically abused during pregnancy & 10.2 & 12.4 \\
\hline Women ever abused during pregnancy & $(\mathrm{N}=131)$ & $(\mathrm{N}=158)$ \\
\hline Ever kicked or punched in abdomen & 36.6 & $24.7^{*}$ \\
\hline Abuser was pregnancy partner† & 99.2 & 99.4 \\
\hline $\begin{array}{l}\text { Women abused by pregnancy partner } \\
\text { Abused by pregnancy partner }\end{array}$ & $(\mathrm{N}=130)$ & $(\mathrm{N}=157)$ \\
\hline before pregnancyt & 83.2 & 86.0 \\
\hline $\begin{array}{l}\text { Women abused by pregnancy partner } \\
\text { before and during pregnancy } \\
\text { Change in level of violence after becoming } \mathrm{p}\end{array}$ & $\begin{array}{c}(\mathrm{N}=109) \\
\text { pregnant }\end{array}$ & $(\mathrm{N}=135)$ \\
\hline Decrease & 41.3 & 54.1 \\
\hline No change & 46.2 & 37.8 \\
\hline Increase & 12.5 & 8.1 \\
\hline
\end{tabular}

conducted because the two contexts were quite different and a regression analysis pooling data from the two areas showed that area of residence was a significant determinant (not shown). All analyses were carried out using Stata version 7.0 (procedure xtlogit).

\section{RESULTS}

\section{Descriptive Statistics}

Ever-pregnant women from the urban site and those from the rural site differed in several ways. Greater proportions of rural women than of urban women were at least 30 ( $57 \%$ vs. 50\%-Table 1), had husbands who had had no education ( $38 \%$ vs. $13 \%$ ), earned income (21\% vs. $15 \%$ ), participated in a savings or credit group (31\% vs. 13\%), were in a marriage that had involved dowry demands ( $53 \%$ vs. 14\%), lived with their in-laws (36\% vs.23\%) and had a mother-in-law who had been physically abused by her husband (17\% vs. 13\%). Greater proportions of urban women than of their rural counterparts had a mother who had been abused by her husband (15\% vs. 10\%), were Muslim (95\% vs. 83\%) and expressed high concern about the level of crime in the community ( $15 \%$ vs. $8 \%$ ).

Ten percent of women from the urban site and $12 \%$ of women from the rural site reported experiencing physical abuse during at least one of their pregnancies (Table 2). Of those, about half had experienced abuse during more than one pregnancy (48\% of urban women and $52 \%$ of rural women-not shown). A greater proportion of abused urban women than of their rural counterparts had ever been kicked or punched in the abdomen while they were pregnant (37\% vs. $25 \%$ ). In the vast majority of cases, the perpetrator of the most recent violence was the partner with whom the woman last became pregnant (99\%) and the abuse was initiated before that pregnancy ( $83 \%$ in the urban site and $86 \%$ in the rural site). Among urban women, $41 \%$ said that the level of abuse had decreased during pregnancy, $46 \%$ said it had remained the same and $13 \%$ said that it had increased; the proportions for rural women were $54 \%$, 38\% and $8 \%$.

\section{Correlates of Violence during Pregnancy}

Because almost all of the women who had been abused during pregnancy had been abused by their husbands, we focused our analysis on factors associated with spousal abuse. Certain factors were associated in logistic regression analyses with physical spousal abuse during pregnancy among both urban and rural women. Both urban and rural women whose mother or mother-in-law had experienced abuse had elevated odds of experiencing such abuse themselves (odds ratios, 2.1-3.4; Table 3). In addition, for each one-point increase in the index score for spousal communication, urban and rural women's odds of physical abuse during pregnancy decreased by $40 \%$ and $30 \%$, respectively.

Some factors were associated with violence in the urban site only. Although women's age was not associated with abuse during pregnancy among rural women, in the urban 
area, being older than 19 was negatively associated with abuse (odds ratios, 0.2-0.3). And compared with urban women whose husbands were uneducated, those whose husbands had had more than 10 years of schooling had lower odds of experiencing physical abuse during pregnancy (0.3). In addition, urban women in the second and fourth income quartiles were less likely than those in the first to have experienced physical violence during pregnancy ( 0.5 and 0.4 , respectively). Finally, women's risk of abuse during pregnancy increased with the proportion of people who reported having high concern about the level of crime in the community (1.1).

Several variables were associated with physical abuse during pregnancy in the rural area, but not the urban area. Having had a marriage that involved dowry demands and being Muslim were positively associated with abuse during pregnancy (odds rations, 1.8 and 3.6, respectively), whereas perceived support from one's natal family in a crisis was negatively associated with such abuse (0.5).

Contrary to general expectation, living with one's inlaws, earning an income and participating in a savings or credit program were not associated with abuse during pregnancy among urban or rural women.

\section{DISCUSSION}

In Bangladesh and elsewhere, violence has been recognized as one of the leading causes of injury-related deaths among pregnant women. ${ }^{53-55}$ Our study, however, did not capture abuse of pregnant women leading to death and might therefore underestimate the level of abuse. In addition, only women who reported lifetime physical violence during their interview were asked about violence during pregnancy; other women might have reported experiencing such abuse if specifically asked about it. Despite these limitations, this study contributes to the literature because of its population-based data and comparability of its findings to those from other research. ${ }^{18}$

About one in 10 women in our sample had ever been abused during pregnancy. When we focused on the last pregnancy during which a woman had been abused, we found that her pregnancy partner was usually the perpetrator and that he had also abused the woman before that pregnancy; this finding is consistent with previous research. $7,18,21,56-57$ Similar to a pattern reported by others, ${ }^{7,56-58}$ violence decreased during pregnancy for more than half of rural women and for about two-fifths of urban women. These proportions are slightly lower than those previously reported. ${ }^{18}$ Abuse remained the same or increased during pregnancy for the rest of the women. And as in other settings, the partner with whom the woman became pregnant was almost always the perpetrator of the abuse.

Previous research has been inconsistent in regard to which demographic factors are associated with abuse during pregnancy. ${ }^{59}$ According to our results, spousal abuse of a woman's mother or mother-in-law is among the strongest determinants of the woman being abused dur-
TABLE 3. Odds ratios (and 95\% confidence intervals) from logistic regression analyses identifying factors associated with spousal violence during pregnancy, by location

\begin{tabular}{|c|c|c|}
\hline Characteristic & Urban & Rural \\
\hline \multicolumn{3}{|l|}{ Age-group } \\
\hline 15-19 (ref) & 1.00 & 1.00 \\
\hline $20-24$ & $0.21(0.08-0.54)^{* *}$ & $0.55(0.21-1.47)$ \\
\hline $25-29$ & $0.30(0.13-0.72)^{* *}$ & $0.49(0.19-1.26)$ \\
\hline$\geq 30$ & $0.20(0.09-0.46)^{* * *}$ & $0.60(0.25-1.46)$ \\
\hline \multicolumn{3}{|l|}{ Husband's education (yrs.) } \\
\hline None (ref) & 1.00 & 1.00 \\
\hline $1-5$ & $0.52(0.18-1.55)$ & $1.11(0.57-2.17)$ \\
\hline $6-10$ & $0.77(0.38-1.58)$ & $0.82(0.49-1.39)$ \\
\hline$\geq 11$ & $0.28(0.13-0.65)^{* *}$ & $0.57(0.26-1.24)$ \\
\hline Earns income & $1.08(0.53-2.24)$ & $1.53(0.92-2.55)$ \\
\hline Member of savings/credit group & $1.11(0.52-2.38)$ & $1.34(0.84-2.12)$ \\
\hline Marriage involved dowry demands & $0.83(0.41-1.69)$ & $1.76(1.10-2.84)^{*}$ \\
\hline In-laws live in household & $0.95(0.48-1.88)$ & $0.72(0.44-1.17)$ \\
\hline May depend on natal family support in crisis & $1.35(0.67-2.74)$ & $0.48(0.28-0.84)^{* *}$ \\
\hline Level of spousal communication & $0.60(0.51-0.71)^{* * *}$ & $0.70(0.60-0.81)^{* * *}$ \\
\hline Mother was abused by her husband & $2.06(1.10-3.85)^{*}$ & $2.43(1.38-4.28)^{* *}$ \\
\hline $\begin{array}{l}\text { Mother-in-law was abused by her husband } \\
\text { Income quartile }\end{array}$ & $2.23(1.22-4.10)^{* *}$ & $3.44(2.17-5.44)^{* * * *}$ \\
\hline I (ref) & 1.00 & 1.00 \\
\hline ॥ & $0.48(0.24-0.93)^{*}$ & $1.13(0.63-2.05)$ \\
\hline III & $0.52(0.22-1.14)$ & $1.29(0.68-2.45)$ \\
\hline IV & $0.36(0.14-0.91)^{*}$ & $1.50(0.76-2.96)$ \\
\hline Muslim & na & $3.57(1.67-7.62)^{* *}$ \\
\hline High concern about level of crime in community† & $1.09(1.04-1.15)^{* * *}$ & $1.00(0.97-1.03)$ \\
\hline
\end{tabular}

ing pregnancy by her own husband, which is consistent with research in Mexico and China. ${ }^{28,38}$ In addition, the negative association between the extent of spousal communication and abuse during pregnancy found in this study supports findings from research in India and China. ${ }^{13,38}$ This study was not able to determine the direction of associations, so it may be that greater couple communication protected women against abuse during pregnancy or that an absence of violence led to better couple communication.

Older age was associated with a lower likelihood of violence during pregnancy among urban women. This fits well with the literature on how a woman's position in the household changes as she ages ${ }^{60}$ and with the existing literature on violence. $6,7,42,43$ Why age is not associated with violence during pregnancy among rural women remains a question. Husband's education beyond 10th grade was associated in both sites with lower odds of violence during pregnancy, consistent with findings from India ${ }^{61}$ and Turkey $^{23}$ that husband's low education is associated with a high risk of abuse during pregnancy.

Although social capital in the form of women's earning income or participating in a savings or credit group was not associated with violence against pregnant women, rural women's expectations of support from their natal family in a crisis reduced their likelihood of such violence. The type of support was not specified in the survey question, and the women had the liberty to mention any kind of support from their natal family, which probably led to the very high reported expectation of support (86\%). Even this loosely defined perceived support from the natal fam- 
ily reduced the likelihood of physical abuse during pregnancy. Further research is needed to understand what this support includes and to identify the pathway through which it influences violence against pregnant women.

The lack of association between a woman's earning income and violence during pregnancy contradicts research from India that found a negative association between the two. ${ }^{61}$ One explanation may be that in our study, women earning any income-regular or irregular, small or largewere considered income earners, although highly irregular and insubstantial income would be unlikely to have a significant effect on violence.

According to our results, urban women with higher household incomes had a lower risk of violence during pregnancy than the poorest women. This is generally in line with the literature, 5,13,38,39 although we cannot explain why the second and fourth income quartiles, but not the third, were significant, or why income was not significant among rural women.

Our finding that rural Muslim women were more likely than rural women of other religions to be abused during pregnancy should be interpreted in light of the historical and cultural differences between Muslims and nonMuslims in Bangladesh. Although, according to religious texts, Muslim women have rights that Hindu women do not have (e.g., to own property, to divorce and to remarry), the reality is paradoxical. For example, village exogamy and physical separation from the natal family make it less likely that a Muslim woman would claim her share of inheritance and more likely that her brothers would seize control of her share of inherited land, regardless of her wishes. ${ }^{62}$ And because of a lack of other options, Muslim women almost never exercise their right to divorce. Moreover, Muslim women in Bangladesh traditionally have less mobility than Hindu women, limiting their access to people and other resources. In contrast, Hindu women tend to be more vocal, more capable of communicating and negotiating, and more self-sufficient.

According to our results, there is a positive association between widespread concerns about crime in the community and violence during pregnancy. Whether this is because of heightened stress levels or other factors is unknown. More research is needed to enhance our understanding of this finding and to identify the pathway through which crime increases the risk of physical violence against pregnant women.

Although the design of our study does not allow us to make causal inferences, the strong associations between physical violence during pregnancy and certain factors have implications for interventions. For example, we found a positive association between a woman's abuse and her family history of abuse. Fathers often express great care and concern for the safety of their daughters, which could be used as a potential entry point to talk more broadly about gender roles and violence. These interventions might potentially address abuse during pregnancy in both rural and urban areas. Promoting older age at marriage and male education beyond the 10th grade could have a similar effect. In urban Bangladesh, reducing overall crime at the community level might also help in reducing abuse during pregnancy.

An important message for advocates, particularly in rural areas, is that the perceived value of daughters needs to be improved, the support of women by their natal family must be promoted and the stigma of women returning to their natal home has to be overcome. Women in Indian families count their fathers and brothers as key partners throughout the period of pregnancy, childbirth and continuing care of their children. ${ }^{63}$ This phenomenon, which is common across South Asia, can also be an entry point for conversations regarding the value of daughters and sisters.

We argue that patriarchal attitudes of both spouses' families, although most clearly those of the husband's family, seem to underlie the association between dowry demand and violence. Patriarchal attitudes among families that demand or agree to dowry contribute to inequality between men and women, creating a space for violence. This does not, however, waive the need for better implementation of the law against dowry. All the recommended efforts need to be accompanied with education, mass awareness-raising campaigns and interventions that aim at changing behaviors and attitudes that tolerate violence against women.

\section{REFERENCES}

1. Newberger EH et al., Abuse of pregnant women and adverse birth outcome. Current knowledge and implications for practice, Journal of the American Medical Association, 1992, 267(17):2370-2372.

2. Gazmararian JA et al., Prevalence of violence against pregnant women, Journal of the American Medical Association, 1996, 275(24): 1915-1920.

3. Valladares E et al., Physical partner abuse during pregnancy: a risk factor for low birth weight in Nicaragua, Obstetrics \& Gynecology, 2002, 100(4):700-705.

4. Council on Scientific Affairs, American Medical Association, Violence against women: relevance for medical practitioners, Journal of the American Medical Association, 1992, 267(23):3184-3189.

5. Gazmararian JA et al., The relationship between pregnancy intendedness and physical violence in mothers of newborns, Obstetrics $E$ Gynecology, 1995, 85(6):1031-1038.

6. Muhajarine $\mathrm{N}$ and D'Arcy C, Physical abuse during pregnancy: prevalence and risk factors, Canadian Medical Association Journal, 1999, 160(7):1007-1011.

7. Stewart DE and Cecutti A, Physical abuse in pregnancy, Canadian Medical Association Journal, 1993, 149(9):1257-1263.

8. Saltzman LE et al., Physical abuse around the time of pregnancy: an examination of prevalence and risk factors in 16 states, Maternal and Child Health Journal, 2003, 7(1):31-42.

9. Martin SL et al., Physical abuse of women before, during and after pregnancy, Journal of the American Medical Association, 2001, 285(12): 1581-1584.

10. Cokkinides VE et al., Physical violence during pregnancy: maternal complications and birth outcomes, Obstetrics \& Gynecology, 1999, 93(5):661-666

11. Nasir K and Hyder A, Violence against pregnant women in developing countries, European Journal of Public Health, 2003, 13(2):105107.

12. Leung WC, Leung TW and Lam YY, The prevalence of domestic violence against pregnant women in a Chinese community, International Journal of Gynaecology and Obstetrics, 1999, 66(1):23-30.

13. Purwar MB et al., Survey of physical abuse during pregnancy, 
Government Medical College and Hospital, Nagpur, India, Journal of Obstetrics and Gynecological Research, 1999, 65(3):195-201.

14. Fikree FF and Bhatti LI, Domestic violence and health of Pakistani women, International Journal of Gynaecology and Obstetrics, 1999, 65(2):195-201.

15. Faruqi N, The women's group report on women speaking about domestic violence, poster presented at the Third Annual National Symposium, Aga Khan University, Karachi, Pakistan, Sept. 21-22, 1996.

16. Deyessa N et al., Magnitude, type and outcomes of violence against women in Bulajira, South Ethiopia, Ethiopian Medical Journal, 1998, 36(2):83-92.

17. International Clinical Epidemiologists Network (INCLEN) and International Center for Research on Women (ICRW), Indiasafe: Studies of Abuse in the Family Environment in India-A Summary Report, New Delhi, India and Washington, DC: INCLEN and ICRW, 2000.

18. García-Moreno C et al., WHO Multicountry Study on Women's Health and Domestic Violence Against Women: Initial Results on Prevalence, Health Outcomes and Women's Responses, Geneva: World Health Organization (WHO), 2005.

19. Bates LM et al., Socioeconomic factors and processes associated with domestic violence in rural Bangladesh, International Family Planning Perspectives, 2004, 30(4):190-199.

20. Wiemann CM et al., Pregnant adolescents: experiences and behaviors associated with physical assault by an intimate partner, Maternal and Child Health Journal, 2000, 4(2):93-101.

21. Dunn LL and Oths KS, Prenatal predictors of intimate partner abuse, Journal of Obstetric, Gynecologic, E Neonatal Nursing, 2004, 33(1):54-63.

22. Taft A, Intimate partner abuse in pregnancy, Obstetrics $\&$ Gynecology, 2001, 3(4):250-253.

23. Karaoglu L et al., Physical, emotional and sexual violence during pregnancy in Malatya, Turkey, European Journal of Public Health, 2006, 16(2):149-156.

24. Jasinski JL, Pregnancy and violence against women: an analysis of longitudinal data, Journal of Interpersonal Violence, 2001, 16(7):713734 .

25. Berenson AB et al., Drug abuse and other risk factors for physical abuse in pregnancy among white non-Hispanic, black, and Hispanic women, American Journal of Obstetrics and Gynecology, 1991, 164(6 Pt. 1):1491-1499.

26. Campbell JC et al., The dynamics of battering during pregnancy, in: Campbell JC, ed., Empowering Survivors of Abuse: Health Care for Battered Women and Their Children, Thousand Oaks, CA, USA: Sage, 1998, pp. 81-89.

27. Campbell JC et al., The influence of abuse on pregnancy intention, Women's Health Issues, 1995, 5(4):214-223.

28. Castro R, Peek-Asa C and Ruiz A, Violence against women in Mexico: a study of abuse before and during pregnancy, American Journal of Public Health, 2003, 93(7):1110-1116.

29. Martin SL et al., Violence and substance abuse among North Carolina pregnant women, American Journal of Public Health, 1996, 86(7):991-998.

30. Hedin LW, Postpartum, also a risk period for domestic violence, European Journal of Obstetrics \& Gynecology and Reproductive Biology, 2000, 89(1):41-45.

31. Martin SL et al., Changes in intimate partner violence during pregnancy, Journal of Family Violence, 2004, 19(4):201-210.

32. Campbell JC et al., Correlates of battering during pregnancy, Research in Nursing and Health, 1992, 15(3):219-226.

33. Taggart $L$ and Mattson $S$, Delay in prenatal care as a result of battering in pregnancy: cross-cultural implications, Health Care for Women International, 1996, 17(1):25-34.

34. Glander SS et al., The prevalence of domestic violence among women seeking abortion, Obstetrics \& Gynecology, 1998, 91(6):1002-
1006.

35. Horrigan TJ, Schroeder AV and Schaffer RM, The triad of substance abuse, violence, and depression are interrelated in pregnancy, Journal of Substance Abuse Treatment, 2000, 18(1):55-58.

36. Jasinski JL, Pregnancy and domestic violence: a review of the literature, Trauma, Violence $\&$ Abuse, 2004, 5(1):47-64.

37. McFarlane J et al., Assessing for abuse during pregnancy: severity and frequency of injuries and associated entry into prenatal care, Journal of the American Medical Association, 1992, 267(23):3176-3178.

38. Su-fang $\mathrm{G}$ et al., Domestic abuse on women in China before, during, and after pregnancy, Chinese Medical Journal, 2004, 117(3):331336

39. Goodwin M et al., Pregnancy intendedness and physical abuse around the time of pregnancy: findings from the Pregnancy Risk Assessment Monitoring System, 1996-1997, Maternal and Child Health Journal, 2000, 4(2):85-92.

40. Campbell JC, Garcia-Moreno C and Sharps P, Abuse during pregnancy in industrialized and developing countries, Violence Against Women, 2004, 10(7):770-789.

41. Bohn DK, Tebben JG and Campbell JC, Influences of income, education, age, and ethnicity on physical abuse before and during pregnancy, Journal of Obstetrics, Gynecology and Neonatal Nursing, 2004, 33(5):561-571

42. Hedin LW et al., Prevalence of physical and sexual abuse before and during pregnancy among Swedish couples, Canadian Medical Association Journal, 1999, 160(7):1007-1011.

43. O'Campo P et al., Verbal abuse and physical violence among a cohort of low-income pregnant women, Women's Health Issues, 1994, 4(1):29-37.

44. Berns SB, Jacobson NS and Gottman JM, Demand-withdraw interaction in couples with a violent husband, Journal of Consulting and Clinical Psychology, 1999, 67(5):666-674.

45. Gordis EB, Margolin G and Vickerman K, Communication and frightening behavior among couples with past and recent histories of physical marital aggression, American Journal of Community Psychology, 2005, 36(1-2):177-191.

46. O'Campo P et al., Uncovering neighbourhood influences on intimate partner violence using concept mapping, Journal of Epidemiology and Community Health, 2005, 59(7):603-608.

47. O'Campo P et al., Violence by male partners against women during the childbearing year: a contextual analysis, American Journal of Public Health, 1995, 85(8):1092-1097.

48. Browning CR, The span of collective efficacy: extending social disorganization theory to partner violence, Journal of Marriage and Family, 2002, 64(4):833-850

49. Koenig MA et al., Individual and contextual determinants of domestic violence in North India, American Journal of Public Health, 2006, 96(1):132-138.

50. National Institute of Population Research and Training (NIPORT), Mitra and Associates and ORC Macro, Bangladesh Demographic and Health Survey, 1999-2000, Dhaka, Bangladesh: NIPORT and Mitra and Associates; and Calverton, MD, USA: ORC Macro, 2001.

51. Centers for Disease Control and Prevention (CDC), PRAMS Model Surveillance Protocol, Atlanta, GA, USA: CDC, 1999.

52. Beusenberg M and Orley JA, User's Guide to the Self Reporting Questionnaire (SRQ), Geneva: WHO, 1994.

53. Dannenberg A et al., Homicide and other injuries as causes of maternal death in New York City, 1987 through 1991, American Journal of Obstetrics and Gynecology, 1991, 172(5):1557-1564.

54. Fildes J et al., The leading cause of maternal death, Journal of Trauma: Injury, Infection, and Critical Care, 1992, 32(5):643-645.

55. Rahman F, Rahman M and Hossain MB, Deaths due to violence and accidents to women of reproductive age in rural Bangladesh, working paper, MCH-FP Extension Project, Dhaka, Bangladesh: ICDDR, B, 1993, No. 99 
56. Helton AS, McFarlane J and Anderson ET, Battered and pregnant: a prevalence study, American Journal of Public Health, 1987, 77(10): 1337-1339.

57. McFarlane J, Abuse during pregnancy: the horror and the hope, AWHONN'S Clinical Issues in Perinatal and Women's Health Nursing, 1993, 4(3):350-362.

58. Campbell JC et al., Correlates of battering during pregnancy, Research in Nursing and Health, 1992, 15(3):219-226.

59. Hotaling GT and Sugarman DB, An analysis of risk markers in husband to wife violence: the current state of knowledge, Violence $\mathcal{E}$ Victims, 1986, 1(2):101-124.

60. Das Gupta M, Life course perspectives on women's autonomy and health outcomes, Health Transition Review, 1996, 6(Suppl.):213-231.

61. Peedicayil A et al., Spousal physical violence against women during pregnancy, BJOG: an International Journal of Obstetrics and Gynaecology, 2004, 111(7):682-687.

62. Cain M, Khanam SR and Nahar S, Class patriarchy and women's work in Bangladesh, Population and Development Review, 1979, 5(3): 405-438.

63. Chopra R, Rethinking pro-feminism: men, work and family in India, <http://www.un.org/womenwatch/daw/egm/men-boys2003/ EP12 Chopra.pdf>, accessed Oct. 17, 2006.

\section{RESUMEN}

Contexto: La violencia contra las mujeres embarazadas es una total violación de los derechos humanos con consecuencias adversas para la salud de la mujer y potencialmente de su feto; sin embargo, pocos estudios han examinado los factores asociados con tales abusos en los países en desarrollo o con base en datos de población.

Métodos: Como parte de un estudio multinacional conducido por la Organización Mundial de la Salud, en 2001 se entrevistó a una muestra de 2,553 mujeres de 15-49 años, de un entorno urbano y otro rural en Bangladesh y que alguna vez estuvieron embarazadas. Se utilizó análisis de regresión logística multinivel para examinar los factores asociados con el abuso físico por parte de los esposos en contra de las mujeres durante el embarazo.

Resultados: Las mujeres urbanas y rurales cuya madre o suegra había sufrido abuso físico por parte del esposo tuvieron mayores probabilidades de padecer abuso durante el embarazo (razones de momios, 2.1-3.4); una mayor comunicación entre los esposos se asoció negativamente con el abuso en ambos entornos ( 0.6 y 0.7). Entre las mujeres urbanas, el hecho de ser mayores de 19 años, de tener un esposo con más de 10 años de educación y de pertenecer a ciertos cuartiles más altos de ingreso se asoció negativamente con el abuso (0.2-0.5); el vivir en una comunidad altamente preocupada por el crimen se asoció positivamente con el abuso (1.1). Entre las mujeres rurales, poder depender del apoyo de su familia natal durante una crisis se asoció negativamente con el abuso (0.5); estar en un matrimonio que involucrara exigencias de dote y el hecho de ser musulmana se asoció positivamente con el abuso (1.8 y 3.6, respectivamente).

Conclusiones: Debería ser ampliamente difundido el mensaje de que una historia familiar de violencia de pareja aumenta el riesgo de que una hija también padezca ese tipo de abuso. Se necesita mayor investigación para determinar si una mejor comunicación en la pareja reduce la probabilidad de violencia, o si la ausencia de violencia conduce a una mejor comunicación en la pareja.

\section{RÉSUMÉ}

Contexte: La violence à l'égard des femmes enceintes est une grave violation des droits de la personne, préjudiciable à la santé de la femme et potentiellement de son foetus. Peu d'études se sont cependant penchées sur les facteurs associés à cette violence dans les pays en développement et peu reposent sur des données de population.

Méthodes: Un échantillon de 2.553 femmes de 15 à 49 ans ayant jamais été enceintes, en un centre urbain et un milieu rural du Bangladesh, a été interrogé en 2001 dans le cadre d'une étude multinationale de l'OMS. Les facteurs associés à la violence conjugale physique faite aux femmes en cours de grossesse sont examinés par analyse de régression logistique multiniveaux.

Résultats: Les femmes des milieux urbains et ruraux dont la mère ou la belle-mère avait subi la violence physique de son mari risquaient davantage d'être elles-mêmes violentées en cours de grossesse (rapport de probabilités, 2,1-3,4). La communication conjugale accrue s'est révélée négativement associée à l'issue dans les deux contextes $(0,6$ et 0,7). Parmi les femmes des milieux urbains, avoir plus de 19 ans, avoir un mari scolarisé pendant plus de 10 ans et appartenir à certains quartiles de revenu supérieur présentent une association négative avec la violence $(0,2-0,5)$, par rapport à une association positive $(1,1)$ pour la vie dans une communauté fort affectée par la criminalité. En milieu rural, pouvoir dépendre du soutien de sa famille natale en cas de crise est un facteur négativement associé à la violence $(0,5)$, contrairement au mariage avec dot et à l'appartenance à la communauté musulmane (association positive de 1,8 et 3,6, respectivement).

Conclusions: Le message que les antécédents familiaux de violence conjugale accroissent le risque pour une fille de la subir elle aussi doit être largement disséminé. Une recherche approfondie est nécessaire pour déterminer si une meilleure communication conjugale réduit la probabilité de la violence ou si l'absence de violence mène à une meilleure communication des couples.

\section{Acknowledgments}

This research was funded by the Urban Primary Health Care Project of Bangladesh (UPHCP), under the auspices of the Government of Bangladesh and the Asian Development Bank (ADB). The protocol and questionnaire came from World Health Organization (WHO) Multi-Country Study on Women's Health and Domestic Violence. The authors are grateful for the commitment of UPHCP$A D B$ and WHO to the Centre's research efforts.

Author contact: ruchira@icddrb.org 